\title{
Organisational Strategic Human Resource Management - The Case of Lehman Brothers
}

\author{
Weng Marc Lim \\ School of Business \\ Monash University \\ E-mail: lim.weng.marc@monash.edu
}

Received: February 6, 2012 Accepted: February 21, 2012 Published: April 1, 2012

doi:10.5296/jmr.v4i2.1368

URL: http://dx.doi.org/10.5296/jmr.v4i2.1368

\begin{abstract}
The emergence of the subprime mortgage crisis - an ongoing economic problem of contracted liquidity in the global credit markets and banking system, in the U.S. has wracked the operations of Lehman Brothers tremendously as their finances were dealt with a huge blow. Continuous hardcore influence of the external environment has further pressurised the human resource aspect of Lehman Brothers. Indefinite effects such as layoff backfire, workers' dissatisfaction, and employment law issues were faced by the once high-flying investment bank. This paper looks at the influence of the external business environment on the human resource management activities using Lehman Brothers as a short case study. The organisational strategic human resource management application is explored and recommendations are presented on how organisations can address human resource challenges from the business environment.
\end{abstract}

Keywords: Organisational strategic human resource management, Lehman Brothers 


\section{Introduction}

Lehman Brothers Holdings Inc., founded in 1850, is a highly diversified global financial services firm based in the U.S. (New York Stock Exchange, 2008). As an innovator in global finance, Lehman serves the financial needs of corporations, governments and municipalities, institutional clients, and high net worth individuals worldwide (Lehman Brothers, 2008). With a long-established reputation for excellence, Lehman is undeniably one of the most pre-eminent franchises in the global equity market.

Yet, it is arguable that the once high-flying investment bank is currently facing its toughest moment since its listing on the New York Stock Exchange Index in 1994 (Anderson \& Dash, 2008). The emergence of the subprime mortgage crisis - an ongoing economic problem of contracted liquidity in the global credit market and banking system, in the U.S. has wracked the operations of Lehman tremendously as their finances were dealt a blow. The undervaluation of real risk in the subprime market would eventually lead to cascades and ripple effects affecting the global economy in which this pre-eminent franchise should be crucially aware of as they operate multinationally. Ultimately, Lehman has been force into a lay off for 1500 workers - 6\% of Lehman's workforce (Boyd, 2008).

It is undeniable that the continuous hardcore influence of the external environment would further pressurise the human resource aspect of Lehman. Indefinite effects such as layoff backfire, workers' dissatisfaction, and employment law issues would be some potential affairs in which Lehman would be facing. Hence, essential management theories and concepts ranging from analytical framework of Jackson and Schuler's (1995) and Kochan and Barocci (1985) to internal human resource management (HRM) practices of Human Resource Planning and Workplace Participants' Rights and Responsibilities can be exercise to address the intimidating threat faced by Lehman. Accordingly, this paper attempts to shed some light on the organisational SHRM application and the recommended organisational HRM response in the case of Lehman Brothers. Insights from this paper will provide organisations and human resource decision makers with informed insights on the application of SHRM and a clearer picture on its application using a short case study.

\section{Discussion}

Following the event of the subprime mortgage crisis, Lehman has been forced into a rethink of the way in which their organisation is managed. Strategic Human Resource Management (SHRM) and HRM has been one of the major developments of this rethinking process.

\section{The Organisational SHRM Application}

Jackson and Schuler (1995) suggest that the adoption of an organisation's particular HRM practices, policies and philosophies and, subsequently, organisational performance are resulted from the various macro-level environmental influences. It was obvious in the context of Lehman that they should opt for the practice of organisational rightsizing in response to the derailing economic environmental condition (Blumberg, 2008). The extent to which their retained employees would react and perform would be greatly determined by the ability of the human resource (HR) department of the organisation in fighting the dilemma. In their 
model, the HR department of the organisation are required to consider the external contexts culture, laws and regulations, politics, and labour and industry partners, relevant to the organisation (Hartel, Fujimoto, Strybosch, \& Fitzpatrick, 2007; Jimenez \& Valle, 2005). Additionally, the model demonstrates the dependency between the process of information interpretation, decision making and communication management in relation to the organisation's technology, structure, size, strategy and life cycle stage (Hartel et al., 2007; Huang, 2001). As a multinational company operating in various regions across the globe, the combination of the globalisation strategy and sustainable technology would be of great importance to an organisation as large as Lehman. Consequently, Lehman's should interpret the identified economical threat and make a final decision that would represent the best solution for both the organisation and its organisational members. This interpretation should take into account all the dependent variables as mentioned above. As Lehman faces an uphill task to reduce their financial burden and prevent job dissatisfaction from a debt-wages situation among its workers as a result of the crisis, it would be wise for Lehman to temporary layoff some of its employees and finding temporary jobs for them in other organisations, and most importantly, when doing so, taking into account the various external contexts as mentioned above. Alternatively, Lehman could consider a pay cut strategy to ease their financial burden effect resulting from the subprime mortgage crisis.

Similarly, Kochan and Barocci (1985) provided an analytical framework representing the informal linkage between the constantly evolving environmental conditions, HRM strategies and policies, and stakeholders' goals and needs. It was particularly important for Lehman to understand the framework proposed by these management gurus as they have to make HR decisions which would satisfy both the organisation and its stakeholders - maintaining organisational profitability, sustainable dividend payment to shareholders, provide a healthy and safe working environment, and customer satisfaction (Lehman Brothers, 2008). The model further suggested that organisational HR analysis should be able to identify the need for HRM strategies and policies to adopt and response to both internal and external organisational changes (Luoma, 1999). An organisational temporary layoff strategy of Lehman's workforce would be a precise strategic response to ease the organisation's financial burden from the subprime mortgage crisis. As mentioned earlier, Lehman could find temporary jobs for these workers so that these workers could bring a rice bowl back home. Ultimately, this would reduce Lehman's financial burden and yet, able to fulfil its responsibility by provide temporary compensating jobs. Furthermore, a precise and complete understanding of the organisational history in terms of its past environmental changes affecting the employment relationship should be considered in the analysis to avoid being in a “history repeating itself” situation (Allan, 1997; Hartel et al., 2007). In June 2007, Lehman decided to permanently layoff 6000 workers which resulted in a backfire by various stakeholders - laid off workers took the organisation to court for unfair dismissal, retained workers felt job insecurity in a fearful environment, and a loss of customers' confidence as seen in the decline of mortgage financing applications in the $4^{\text {th }}$ quarter of 2007 onwards (Anderson \& Dash, 2008; Boyd, 2008; Lehman Brothers, 2008). Thus, to avoid being in the news of similar consequences, Lehman should layoff its workers as according to what is constituted in the employment law. If the employment does not permit that act, Lehman could 
consider revising a job package for its employees - giving a pay cut but an increase in non-monetary benefits such as increase in sick leaves. Ultimately, Lehman's SHRM policies should be able to silent or at the very least, minimise the effect of the crisis as well as maintaining the interests of its stakeholders.

\section{The Organisational Recommended HRM Response}

If HRM do not take the lead, who will? Undeniably, various HRM strategies and practices, ranging from HR planning, staffing practices, performance and appraisal, and workplace participants' rights, responsibility and safety in the workplace, regulates the stability of an organisation's HR efficiently and effectively (Hartel et al., 2007; Jimenez \& Valle, 2005; Luoma, 1999). However, not all internal HRM strategies and practices are of relevance in ALL situations. In the case of Lehman, two major internal HRM practices are of relevance in relation to their response to the derailing situation: HR planning (HRP) and workplace participants' rights and responsibility.

A strategic plan detailing the fundamental principles and criteria underlying such programmes is essential for success (Zeffane \& Mayo, 1994). Most strategic-based organisations are now finding it conducive to evaluate the pretentiousness of their reduction measures well in advance as over-employing or under-employing of workers might hinder endeavours to change the organisation's niche (Kaye, 1999; Zeffane \& Mayo, 1994). The traditional 'one plan for all situations' - Lehman continuous permanent layoff plans for its workers in wobbly conditions, can no longer be used as a planning anchor in low-growth, volatile business environment. Various management gurus have pledge their support for the HRP practice as it is of vital assistance in deciding which jobs are essential, which jobs will be lost, and to determine whether terminations should be concurrent or implemented using a phase-down approach (Kaye, 1999; Khandekar \& Sharma, 2005; Zeffane \& Mayo, 1994). Consequently, this brings about the justification of importance and essentiality for Lehman to conduct a HRP by engaging themselves in an ongoing environmental scanning of both the internal and external labour market in line with an analysis of their organisational objectives, strategies and policies in order to determine the right quantity and quality of employees when and where necessary (Chew \& Goh, 1997; Hartel et al., 2007). In other words, it would be as simple as 'finding the right person for the right job at the right time'. Judging by the amount of workers laid off by Lehman, it would suggest that the pre-eminent global franchise had encounter a failure in their HR plan leading to a labour surplus in which they had to lay off following the subprime mortgage crisis. Identifying and selecting the appropriate number of required workers would have deter the rightsizing activities in which Lehman have deliberately conducted in June 2007 and impending on September 2008 (Anderson \& Dash, 2008; Boyd, 2008). Ultimately, wastage of resources and excessive payroll costs would not have occurred and need not contribute to the extreme financial burden currently faced by Lehman.

The workplace participants' rights and responsibility is another HR practice in which Lehman must emphasis a great notice on. The employment relationship between Lehman and its employees are determined by the employment contract formed between the respective parties 
(Lehman Brothers, 2008; Norman \& Fowler, 1989). Subsequently, the employment law in all countries around the globe sets the minimum standards and conditions for employment in a given region (Norman \& Fowler, 1989). As the employment options varies and are rather complex, it is essential for Lehman to have a current and accurate understanding of the employment law both in the home country and host country. Reviewing the situation in which laid off employees of Lehman launched a snatching attack in bringing the organisation to court following their claimed unfair dismissal in June 2007, Lehman was seen to be somewhat oblivious in regards to the employment law (Anderson \& Dash, 2008; Boyd, 2008). Instead, it was rather obvious that ideas on how to reduce financial losses were dominating the minds of the organisation's irrational managerial executives. The HR practitioners should have known better that dismissing a workman without just cause or excuse by his or her employer may result in dismissed employee(s) making representations to the Director General of Industrial Relations to be reinstated to their former appointment - s20(1) Industrial Relations Act '67 (Gee \& Kleiner, 1996). Nonetheless, what has been done in the past cannot be erased. Currently, it would be essential for Lehman to call off the impending permanent layoff of 1500 workers before September 2008 to avoid another tragedy similar to the one in June 2007 (Boyd, 2008; Snape, 1994). Lehman would have a duty to provide work to their employees in accordance to their employment contract and a duty to pay remuneration if employees are ready and willing to work or have already performed instructed work (Norman \& Fowler, 1989; Tiangco \& Kleiner, 1999). If there is an insist on a permanent laying off the 1500 workers, it would be essential for Lehman to come to an agreement with their potential laid off workers to avoid future dilemma and conflicts, and provide job security assurance to retained workers to avoid reduction in organisational cohesiveness (Blumberg, 2008; Snape, 1994).

\section{Conclusion}

In the modern global economy, organisations, without doubt, would face various ambiguous external environmental pressures, particularly influencing the human resource aspect of the organisation. In the context of Lehman, is was seen that the subprime mortgage crisis faced by this once-high flying investment bank had led to various negative outcomes - laid off workers took the organisation to court for unfair dismissal, retained workers felt job insecurity in a fearful environment, and a loss of customers' confidence as seen in the decline of mortgage financing applications in the $4^{\text {th }}$ quarter of 2007 onwards (Anderson \& Dash, 2008; Boyd, 2008; Lehman Brothers, 2008).

Thus, with reference to the momentous context, two relevant SHRM theories were used to explain how Lehman could improve in its organisational situation - the analytical frameworks of Jackson and Schuler's (1995) and Kochan and Barocci (1985). In the integration of former framework to the organisational situation, Lehman was recommended to adopt the HRM practice of rightsizing - temporary layoffs and pay cut, in response to the derailing economic environmental conditions in which the decision was believed to reduce the financial burden of the organisation and prevent job dissatisfaction from a debt-wages situation among its workers. It was further analysed that the extend to which their retained employees would react and perform was seen to be greatly determined by the ability of the 
HR department in fighting the dilemma (Jimenez \& Valle, 2005). In contrast, the latter integrated situational framework presented the importance for Lehman to understand the framework in order to make HR decisions which would satisfy both the organisation and its stakeholders (Lehman Brothers, 2008). Again, the framework also identified the need for Lehman to adopt HRM strategies with response to the changes in the external environment temporary layoff plan and job repackaging. Furthermore, an understanding of the organisational history was emphasised in this model in which Lehman was rather poor potentially leading them to a "history repeating itself" situation.

Consequently, two internal HRM practices were suggested to take the lead to haul Lehman out of their dreadful situation - HRP and workplace participants' rights and responsibilities. In the HRP recommendation, Lehman traditional 'one plan for all situations' was condemned. Instead, the importance and essentiality for Lehman to conduct a HRP taking into account continuous environmental scanning were emphasised as their former HRP was a failure permanently laying off labour surplus in which wastage of resources and excessive payrolls could have been avoided (Anderson \& Dash, 2008; Boyd, 2008; Chew \& Goh, 1997; Hartel et al., 2007). Conversely, the workplace participants' rights and responsibilities emphasised an understanding of the employment law as they pointed out Lehman's lack of understanding - permanent layoff without just cause or excuse (Anderson \& Dash, 2008; Boyd, 2008). However, what has been done cannot be erased. This lead to the suggestion of Lehman to call off their impending layoff plan to avoid the repeat of June 2007. In the event where layoff is insisted, Lehman's HR practitioners are recommended to come to an agreement with their potential laid off workers to avoid future dilemma and conflicts, and provide job security assurance to retained workers to avoid reduction in organisational cohesiveness (Blumberg, 2008; Snape, 1994).

Conclusively, it would be essential for Lehman to provide a job-security assurance to its existing workers, consider temporary layoff plans, pay cut strategies, job repackaging, study its organisational history, have an in-depth understanding of the employment law, and engage in HRP consistent with continuous environmental scanning in order to overcome the issue and sustain a smooth flow of organisational operations.

\section{Recommendations}

Five short recommendations that Lehman Brothers - both the organisation and its HR practitioners, should use to response to the issue.

1. Lehman should gain an in-depth understanding of the employment law in the home country and host country.

2. Lehman should engage in continuous environmental scanning to identify

environmental changes which could affect the organisation.

3. Lehman should find temporary jobs for workers that they want to layoff temporarily.

4. Lehman should consider a pay cut strategy to reduce its financial burden. 
5. Lehman should provide an assurance of job security to existing workers to maintain workforce stability.

\section{References}

Allan, P. (1997). Minimizing employee layoffs while downsizing: employer practices that work. International Journal of Manpower, 18(7), 576-596. http://dx.doi.org/10.1108/01437729710186437

Anderson, J., \& Dash, E. (2008, August 28). For Lehman, More Cuts and Anxiety. Retrieved August 31, 2008, from http://www.nytimes.com/2008/08/29/business/29wall. html?_r=1\&em\&oref=slogin

Blumberg, D. (2008, August 29). More Layoffs at Lehman Brothers. Retrieved August 31, 2008, from http://www.wnyc.org/news/articles/107512

Boyd, R. (2008, August 28). Lehman to lay off 1,500. Retrieved August 31, 2008, from http://money.cnn.com/2008/08/28/news/companies/news.lehman.fortune/index.htm?section= money_latest

Chew, I., \& Goh, M. (1997). Some future directions of human resource practices in Singapore. Career Development International, 238-244. http://dx.doi.org/10.1108/13620439710174642

Gee, G., \& Kleiner, B.H. (1996). How to Downsize Legally. Managerial Law, 38(9), 22-31. http://dx.doi.org/10.1108/eb022469

Hartel, C.E.J., Fujimoto, Y., Strybosch, V.E., \& Fitzpatrick, K. (2007). Human Resource Management: Transforming Theory into Innovative Practice. Malaysia: Pearson Education Australia.

Huang, T.C. (2001). The effects of linkage between business and human resource management strategies. Personnel Review, 30(2), 132-151. Retrieved from

Jackson, S., \& Schuler, R. (1995). Understanding human resource management in the context of organisations and their environments. Annual Review of Psychology, 46(2), 237-264.

Jimenez D.J., \& Valle, R.S. (2005). Innovation and human resource management fit: an empirical study. International Journal of Manpower, 26(4), 364-381. http://dx.doi.org/10.1108/01437720510609555

Kaye, L. (1999). Strategic human resource management in Australia: the human cost. International Journal of http://dx.doi.org/10.1108/01437729910302750

Khandekar, A., \& Sharma, A. (2005). Managing human resource capabilities for sustainable competitive advantage: An empirical analysis from Indian global organisations. Education + Training, 47(8/9), 628-639.

Kochan, T.A., \& Barocci, T.A. (1985). Human resource management and industrial relations. 
Boston: Little Brown.

Lehman Brothers. (2008). Our Firm. Retrieved August 31, 2008, from http://www.lehman.com/

Luoma, M. (1999). The essence of HRD orientation: evidence from the Finnish metals industry. Journal of European Industrial Training, 23(3), 113-120. http://dx.doi.org/10.1108/03090599910261781

New York Stock Exchange. (2008, August 29). Lehman Brothers Holdings Inc. Retrieved August 31, 2008, from http://www.nyse.com/about/listed/leh.html

Norman, R.N., \& Fowler, M.P. (1989). Recent Changes in UK Employment Law. International Journal of $\quad$ Manpower, http://dx.doi.org/10.1108/EUM0000000000859

Snape, E. (1994). Union Organizing in Britain: The Views of Local Full-time Officials. Employee Relations, 16(8), 48-62. http://dx.doi.org/10.1108/01425459410073942

Tiangco, E.O., \& Kleiner, B.H. (1999). New developments concerning negligent hiring. Journal of Workplace Learning, 11(1), 16-21. http://dx.doi.org/10.1108/13665629910250915

WNYC Newsroom. (2008, August 29). Major Layoffs Expected at Lehman Brothers. Retrieved August 31, 2008, from http://www.wnyc.org/news/articles/107490

Zeffane, R., \& Mayo, G. (1994). Rightsizing: The Strategic Human Resource Management Challenge of the 1990s. Management Decision, 32(9), 5-9. http://dx.doi.org/10.1108/00251749410071568 